\section{$\underset{\text { hommes }}{\text { \& migrations }}$}

\section{Hommes \& migrations}

Revue française de référence sur les dynamiques

migratoires

\section{$1291 \mid 2011$}

Diasporas sri lankaises

\title{
Amin Maalouf, Le Dérèglement du monde
}

Paris, Le Livre de poche, 2010, 320 pages, 6,5 euros

\section{Mustapha Harzoune}

\section{Q OpenEdition}

\section{Journals}

\section{Édition électronique}

URL : http://journals.openedition.org/hommesmigrations/714

DOI : 10.4000/hommesmigrations.714

ISSN : 2262-3353

\section{Éditeur}

Musée national de l'histoire de l'immigration

\section{Édition imprimée}

Date de publication : 1 mai 2011

Pagination : 162-163

ISSN : 1142-852X

\section{Référence électronique}

Mustapha Harzoune, « Amin Maalouf, Le Dérèglement du monde », Hommes \& migrations [En ligne],

1291 | 2011, mis en ligne le 29 mai 2013, consulté le 22 septembre 2020. URL : http://

journals.openedition.org/hommesmigrations/714; DOI : https://doi.org/10.4000/hommesmigrations. 714

Ce document a été généré automatiquement le 22 septembre 2020.

Tous droits réservés 


\title{
Amin Maalouf, Le Dérèglement du monde
}

Paris, Le Livre de poche, 2010, 320 pages, 6,5 euros

\author{
Mustapha Harzoune
}

\section{RÉFÉRENCE}

Amin Maalouf, Le Dérèglement du monde, Paris, Le Livre de poche, 2010, 320 pages, 6,5 euros

1 “Je l'écris sans détour, et en pesant mes mots: c'est d'abord là, auprès des immigrés, que la grande bataille de notre époque devra être menée, c'est là qu'elle sera gagnée ou perdue. Ou bien l'Occident parviendra à les reconquérir, à retrouver leur confiance, à les rallier aux valeurs qu'il proclame, faisant d'eux des intermédiaires éloquents dans ses rapports avec le reste du monde; ou bien ils deviendront son plus grave problème."

2 Voilà qui est dit! Le précieux romancier franco-libanais, polyglotte à cheval sur l'Occident et le monde arabe, citoyen et intellectuel qui embrasse de son regard gourmand et de sa plume élégante le vaste monde devenu "village planétaire", revient à l'essai. Après ses percutantes Identités meurtrières, il revient aider ses contemporains à mettre un peu d'ordre dans un monde déréglé par la montée du "fanatisme", de la “ violence", de "l'exclusion" et du "désespoir", "[...] un monde où les appartenances sont exacerbées, notamment celles qui relèvent de la religion; où la coexistence entre les différentes communautés humaines est, de ce fait, chaque jour un peu plus difficile ; et où la démocratie est constamment à la merci des surenchères identitaires".

3 Amin Maalouf a écrit son livre bien avant le "Printemps arabe". Pour autant, son diagnostic demeure utile. Maalouf insiste sur l'exigence de "dignité" et de "légitimité" dans cette "aire culturelle arabo-musulmane" qui en manque tant - et l'action américaine, en Indonésie ou en Iran par exemple, n'est pas pour rien dans cet état de fait, dixit l'auteur. Aujourd'hui, il se pourrait que ce monde arabe en finisse avec "l'indigence de sa conscience morale" et voie émerger en son sein de nouvelles légitimités, dont les effets, 
comme hier les dérèglements, pourraient se répandre "sur toute l'étendue de la planète". Car le monde est global et c'est de ce constat que part Maalouf. Si la légitimité manque (ou manquait) au monde arabe, elle déserte aussi les pays d'Occident qui, faute de suprématie économique et d'autorité morale, font de l'intervention militaire "une méthode de gouvernement" de la planète. Car, selon Amin Maalouf, la civilisation occidentale "créatrice de valeurs universelles" reste partagée "entre son désir de civiliser le monde et sa volonté de le dominer". Et pourtant, selon l'universalité occidentale, “ l'humanité est une" et "aucun peuple sur terre n'est fait pour l'esclavage, pour la tyrannie, pour l'arbitraire, pour l'ignorance, pour l'obscurantisme, ni pour l'asservissement des femmes. Chaque fois qu'on néglige cette vérité de base, on trahit l'humanité, et on se trahit soi-même".

4 Le monde étant global, "nous sommes en train de sombrer ensemble" et, dans ce monde partagé et unique, "les problèmes ne peuvent être résolus que si l'on réfléchit globalement, comme si l'on était une vaste nation plurielle, tandis que nos structures politiques, juridiques et mentales nous contraignent à réfléchir et à agir en fonction de nos intérêts spécifiques - ceux de nos États, de nos électeurs, de nos entreprises, de nos finances nationales". Voilà pourquoi Amin Maalouf souhaite l'instauration d'une "sorte de 'gouvernement global". Et voir comment la radioactivité, les virus, les capitaux, les marchandises, le droit ou les migrants se jouent des frontières, on comprend que les cadres nationaux vacillent.

5 Mais pour cela il conviendrait d'en finir aussi avec "l'esprit d'apartheid". Basta des présupposés ethniques sur "ces gens-lă" qui "ne sont pas comme nous". Ce pseudo-“" respect' de l'Autre est une forme de mépris, et le révélateur d'une détestation".

6 Ainsi, si l'homme africain n'est pas assez entré dans l'Histoire, l'Arabe, lui, poireauterait encore dans l'antichambre. Son passé, son présent et son avenir seraient, à l'ombre des minarets, écrit ad aeternam. "Et c'est ainsi qu'Allah est grand" aurait peutêtre écrit Alexandre Vialatte. L'Occident oublierait-il ses propres leçons? Le devenir des sociétés est le résultat de l'Histoire et non le fruit d'un commandement divin, rappelle l'auteur, de sorte qu' expliquer sommairement par la 'spécificité de l'islam' tout ce qui se passe dans les différentes sociétés musulmanes, c'est se complaire dans les lieux communs, et c'est se condamner à l'ignorance et à l'impuissance". Un peu moins de religion et un peu plus d'attention aux peuples - arabes mais aussi européens. Et fissa encore ! Car il y a danger. "Dans le 'village global' d'aujourd'hui, une telle attitude n'est plus tolérable, parce qu'elle compromet les chances de coexistence au sein de chaque pays, de chaque ville, et prépare pour l'humanité entière d'irréparables déchirements et un avenir de violence."

7 Alors, que faire? Fi du "passéisme" et de "la relativité des valeurs", il faut imaginer "un nouvel humanisme" et "entrer de plain-pied dans une tout autre phase de l'aventure humaine. Une phase où tout doit être inventé à nouveau - les solidarités, les légitimités, les identités, les valeurs, les repères".

8 Et le romancier reprend le dessus : "Sortir par le haut" du "dérèglement" "exige d'adopter une échelle des valeurs basée sur la primauté de la culture". La culture "peut nous aider à gérer la diversité humaine", nous aider à nous connaître les uns les autres, "intimement". Et “ l'intimité d'un peuple, c'est sa littérature".

9 Il faut vite en finir avec cette attitude qui renvoie les immigrés à leur religion ou à leur communauté. Comme Driss Chraïbi ou Ying Chen avant lui, Amin Maalouf demande au contraire que chacun s'enrichisse de l'individualité de l'autre, émancipée de toute appartenance. Le comportement des pays européens vis-à-vis des immigrés est une “ question cruciale". Pour l'heure, en France comme en Grande- Bretagne, on tourne le dos à ce "nouvel humanisme". Or "l'immigré a soif [...] de dignité culturelle [dont] [...] la 
composante la plus irremplaçable est la langue". "L'appartenance religieuse est exclusive, l'appartenance linguistique ne l'est pas; tout être humain a vocation à rassembler en lui plusieurs traditions linguistiques et culturelles."

10 Une fois de plus, Amin Maalouf s'élève contre les communautarisations en cours et montre le rôle de trait d'union que les immigrés pourraient tenir au sein d'une diversité harmonieuse. Encore faudrait-il que l'on cessât de leur chercher des poux dans la tête... Ce qui semble mal parti!

\section{NOTES}

1. Paris, Grasset, 2009 pour la première édition. 